\title{
A gas chromatographic instrument for measurement of hydrogen cyanide in the lower atmosphere
}

\author{
J. L. Ambrose ${ }^{1,2, *}$, Y. Zhou ${ }^{2, * *}$, K. Haase ${ }^{1,2,{ }^{* * *}}$, H. R. Mayne ${ }^{1}$, R. Talbot ${ }^{2, * * *}$, and B. C. Sive ${ }^{2, * *}$ \\ ${ }^{1}$ Department of Chemistry, University of New Hampshire, Durham, New Hampshire, USA \\ ${ }^{2}$ Climate Change Research Center, Institute for the Study of Earth Oceans and Space, University of New Hampshire, \\ Durham, New Hampshire, USA \\ *now at: Science and Technology Program, University of Washington-Bothell, Bothell, Washington, USA \\ *** now at: Department of Chemistry, Appalachian State University, Boone, North Carolina, USA \\ **** now at: United States Geological Survey, Washington D.C., USA \\ ${ }^{* * * *}$ now at: Department of Earth and Atmospheric Sciences, University of Houston, Houston, Texas, USA
}

Correspondence to: J. L. Ambrose (jlambros@u.washington.edu)

Received: 31 December 2011 - Published in Atmos. Meas. Tech. Discuss.: 27 January 2012

Revised: 20 April 2012 - Accepted: 7 May 2012 - Published: 1 June 2012

\begin{abstract}
A gas-chromatographic (GC) instrument was developed for measuring hydrogen cyanide $(\mathrm{HCN})$ in the lower atmosphere. The main features of the instrument are (1) a cryogen-free cooler for sample dehumidification and enrichment, (2) a porous polymer PLOT column for analyte separation, (3) a flame thermionic detector (FTD) for sensitive and selective detection, and (4) a dynamic dilution system for calibration. We deployed the instrument for a $\sim 4$ month period from January-June, 2010 at the AIRMAP atmospheric monitoring station Thompson Farm 2 (THF2) in rural Durham, NH. A subset of measurements made during 3-31 March is presented here with a detailed description of the instrument features and performance characteristics. The temporal resolution of the measurements was $\sim 20 \mathrm{~min}$, with a $75 \mathrm{~s}$ sample capture time. The $1 \sigma$ measurement precision was $<10 \%$ and the instrument response linearity was excellent on a calibration scale of $0.10-0.75 \mathrm{ppbv}( \pm 5 \%)$. The estimated method detection limit (MDL) and accuracy were $0.021 \mathrm{ppbv}$ and $15 \%$, respectively. From 3-31 March 2010, ambient HCN mixing ratios ranged from $0.15-1.0 \mathrm{ppbv}( \pm 15 \%)$, with a mean value of $0.36 \pm 0.16 \mathrm{ppbv}(1 \sigma)$. The approximate mean background $\mathrm{HCN}$ mixing ratio of $0.20 \pm 0.04 \mathrm{ppbv}$ appeared to agree well with tropospheric column measurements reported previously. The GC-FTD HCN measurements were strongly correlated with acetonitrile $\left(\mathrm{CH}_{3} \mathrm{CN}\right)$ measured concurrently with a proton transfer-reaction mass spectrometer (PTR-MS), as anticipated given our understanding that the
\end{abstract}

nitriles share a common primary biomass burning source to the global atmosphere. The nitriles were overall only weakly correlated with carbon monoxide (CO), which is reasonable considering the greater diversity of sources for CO. However, strong correlations with $\mathrm{CO}$ were observed on several nights under stable atmospheric conditions and suggest regional combustion-based sources for the nitriles. These results demonstrate that the GC-FTD instrument is capable of making long term, in-situ measurements of $\mathrm{HCN}$ in the lower atmosphere. To date, similar measurements have not been performed, yet they are critically needed to (1) better evaluate the regional scale distribution of $\mathrm{HCN}$ in the atmosphere and (2) discern the influence of biomass burning on surface air composition in remote regions.

\section{Introduction}

Biomass burning (BB) is generally thought to be the major source of hydrogen cyanide $(\mathrm{HCN})$ in the atmosphere ( $\mathrm{Li}$ et al., 2000, 2003, 2009; Shim et al., 2007). Pyrolysis of nitrogen atom $(\mathrm{N})$-containing functionalities in the fuel is the primary mechanism proposed for $\mathrm{HCN}$ release from biomass combustion (Johnson and Kang, 1971; Glarborg et al., 2003). Hydrogen cyanide has been measured from field biomass fires (Hurst et al., 1994a, b; Goode et al., 2000; Yokelson et al., 2007; Crounse et al., 2009), and from laboratory biomass

Published by Copernicus Publications on behalf of the European Geosciences Union. 
combustion systems (Lobert et al., 1991; Holzinger et al., 1999; Christian et al., 2004; Becidan et al., 2007). Elevated free tropospheric HCN columns were measured from the International Scientific Station of the Jungfraujoch (ISSJ) in the Swiss Alps by solar infrared (IR) spectroscopy during 1998 , coinciding with a period of intense BB in the tropics (Rinsland et al., 2000).

Low HCN mixing ratios were observed by aircraft in urban plumes off the Pacific coast of the United States, suggesting that automobile emissions make a small contribution to the total global HCN budget (Singh et al., 2003). However, it is well known that $\mathrm{HCN}$ is an important intermediate in combustion-based nitric oxide (NO) formation, even for non-N containing fuels (Dagaut et al., 2008). Variability in the correlation between column abundances of HCN and carbon monoxide (CO), a general combustion tracer, measured at ISSJ suggested that fossil fuel combustion sources of HCN could be significant (Rinsland et al., 2000). Two recent studies have reported the direct measurement of $\mathrm{HCN}$ in automobile exhaust samples (Karlsson, 2004; Baum et al., 2007). While the correlations between $\mathrm{HCN}$ and $\mathrm{CO}$ in vehicle exhaust plumes at a suburban site in Boston, MA were positive, they were highly variable (Knighton et al., 2009). Additionally, domestic coal burning could potentially be an important fossil fuel source of $\mathrm{HCN}$ in certain regions ( $\mathrm{Li}$ et al., 2003).

Moreover, non-combustion-based anthropogenic HCN sources cited previously include fugitive emissions from industry and episodic release associated with the use of $\mathrm{HCN}$ as a fumigant (Singh et al., 2003). Such sources are expected to be minor.

The significance of biogenic emissions to the global HCN budget has long been questioned (Cicerone and Zellner, 1983; Mahieu et al., 1997; Rinsland et al., 2000; Fall et al., 2001; Li et al., 2003; Singh et al., 2003; Shim et al., 2007). Many plant species are known to produce cyanogenic glycosides, which may produce HCN through enzymatic mechanisms (Vetter, 2000). A large number of plant species have been shown to be potential HCN emitters (Aikman et al., 1996). It was determined for several plant species that cyanogenic glycosides and the enzymes responsible for $\mathrm{HCN}$ production are separately compartmentalized within the plant tissue, which presumably prevents large scale $\mathrm{HCN}$ release (Poulton and $\mathrm{Li}, 1994)$. Physical damage to the plant tissue, e.g., by herbivory, is therefore likely necessary to induce plant-based, biogenic $\mathrm{HCN}$ release to the atmosphere (Fall et al., 2001). Emissions of HCN from wounded plant tissue samples were directly observed using negative ionchemical ionization mass spectrometry (NI-CIMS) with hydroxide $\left(\mathrm{HO}^{-}\right)$as the reagent ion, and by selected ion flow tube-mass spectrometry (SIFT-MS) with $\mathrm{HO}^{-}$and hydronium $\left(\mathrm{H}_{3} \mathrm{O}^{+}\right)$as reagent ions (Custer et al., 2000, 2003). Additionally, bacterial $\mathrm{HCN}$ emissions from laboratory cultures were measured by SIFT-MS with $\mathrm{H}_{3} \mathrm{O}^{+}$as reagent ion (Španìl et al., 2004). A positive matrix factorization analy- sis of airborne trace-gas measurements over the western Pacific suggested that biogenic emissions were potentially of comparable importance to biomass burning emissions in that region during the spring of 2001 (Shim et al., 2007).

The atmospheric chemistry of HCN has been described in detail previously (Cicerone and Zellner, 1983), with some modifications discussed by Kleinböhl et al. (2006). Reaction with hydroxyl radical $(\mathrm{OH})$ in the troposphere is the primary gas-phase loss mechanism for HCN in the atmosphere, imposing a lifetime of a few years. Reaction with singlet oxygen atom $\left(\mathrm{O}^{1} \mathrm{D}\right)$ is estimated to become important in the lower stratosphere. Uptake to the ocean has been shown to be the dominant atmospheric sink for HCN (Li et al., 2000). Estimates of the HCN lifetime with respect to ocean uptake range from 2 to 5.3 months (Li et al., 2000, 2003; Singh et al., 2003). However, details of the ocean sink mechanism are lacking at this time.

Although HCN does not appear to play a significant role in atmospheric chemistry, it may represent an important nitrogen source in remote oceanic environments ( $\mathrm{Li}$ et al., 2000). Additionally, it is expected to be a useful tracer for BB emissions (Yokelson et al., 2007; Crounse et al., 2009). Finally, biogenic production of $\mathrm{HCN}$ and carbonyl compounds are known to be associated (Vetter, 2000); strong, positive correlations were observed between biogenic emissions of HCN and carbonyl compounds from wounded tissue of several cyanogenic plants (Custer et al., 2003).

Most previous atmospheric $\mathrm{HCN}$ measurements have been made using solar IR spectroscopy (c.f., Coffey et al., 1981; Zhao et al., 2002; Kleinböhl et al., 2006 and references therein; Rinsland et al., 2007). In-situ HCN measurements were first made in the stratosphere by NI-CIMS (e.g., Schneider et al., 1997). Later, in-situ measurements in the troposphere were made by (1) long-path Fourier transform IR (FTIR) spectroscopy within BB plumes (Goode et al., 2000; Yokelson et al., 2007), (2) a GC system, using a reduction gas detector (RGD) (Singh et al., 2003), (3) NI-CIMS using trifluoromethoxide $\left(\mathrm{CF}_{3} \mathrm{O}^{-}\right)$as reagent ion (Crounse et al., 2006, 2009; Yokelson et al., 2007), and (4) PTRMS (Knighton et al., 2009). Additionally, matrix-isolation FTIR spectroscopy was performed offline for measurement of HCN in grab samples of BB plumes (Hurst et al., 1994a, b). In-situ measurements of background $\mathrm{HCN}$ levels by IR spectroscopy have not been reported. Instruments based on NI-CIMS typically exhibit reduced sensitivity at elevated $\mathrm{H}_{2} \mathrm{O}$ vapor pressures (Crounse et al., 2006); therefore their use has been inhibited in much of the lower atmosphere. The low proton affinity of HCN (Holzinger et al., 1999; Španìl et al., 2004) and potential interference from ethene (Knighton et al., 2009) have complicated measurement of HCN in the atmosphere by PTR-MS, though Knighton et al. (2009) demonstrated that these issues may be overcome through calibration. In addition to the challenges of measuring $\mathrm{HCN}$ in the atmosphere by NI-CIMS and PTR-MS, sample dilution 
(a)

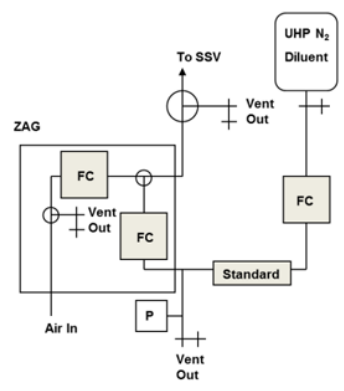

(b)

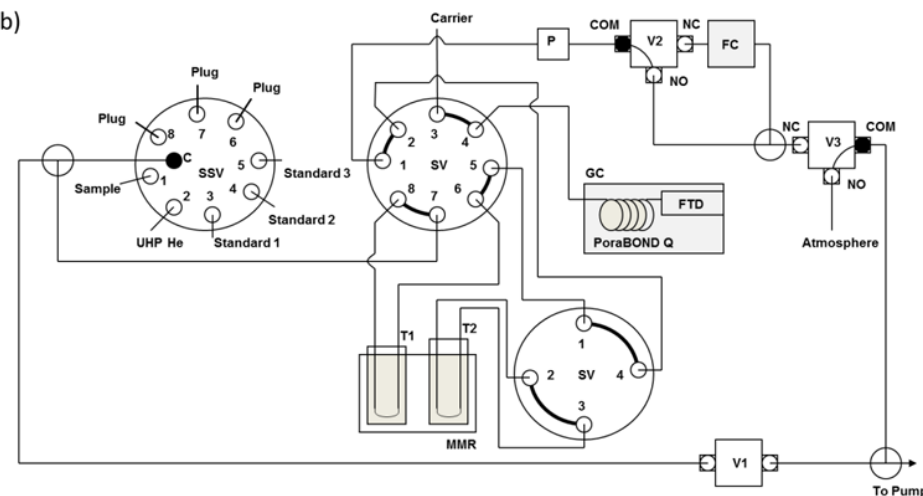

Fig. 1. Schematic of the GC-FTD instrument. System segregated into (a) standard dilution, (b) sample capture and analysis components. Configuration in (b) shows 8-port SV in position A and 4-port SV in position B (for sample desorption). Components: SV, switching valve; SSV, stream select valve; V, solenoid valve; P, pressure gauge; FC, flow controller; MMR, Cryofocus System; T1, sample dehumidification chamber; T2, sample enrichment chamber; ZAG, Apel-Reimer zero air generator (with only the dilution components shown for clarity). The common (COM), normally open (NO) and normally closed (NC) ports of the 3-way solenoid valves are labeled for completeness.

in the flow tube buffer gas reduces detectability via SIFT-MS (Blake et al., 2009).

Considerable uncertainties remain regarding contributions of different combustion and non-combustion sources to the budget and ambient levels of HCN on regional scales. Measurements in the lower atmosphere may provide the best means for reducing such uncertainties, but are lacking at this time. Only one report of in-situ surface measurements of $\mathrm{HCN}$ has appeared in the literature (Knighton et al., 2009). In order to improve our understanding of the distribution of $\mathrm{HCN}$ in the lower atmosphere a GC instrument, incorporating a flame thermionic detector (FTD), was developed and deployed for atmospheric measurements of $\mathrm{HCN}$ at the AIRMAP atmospheric monitoring station THF2 during January-June 2010. A description of the measurement site and supporting measurements used in this work, together with a detailed description of the GC-FTD instrument, including operating parameters, the calibration scheme, and data analysis methods are presented. Instrument performance is discussed and ambient measurements are presented to demonstrate the utility of this system. For this analysis, we focus on a subset of measurements made during 3-31 March, when (1) there were relatively few interruptions in sample collection, (2) acetonitrile $\left(\mathrm{CH}_{3} \mathrm{CN}\right)$ was concurrently measured by PTR-MS, and (3) ambient levels of the nitriles exhibited relatively large ranges. Further analyses of the ambient measurements are presented separately (e.g., Talbot et al., 2011).

\section{Experimental}

\subsection{Measurement site location}

The GC-FTD instrument was deployed for ambient measurements between 24 January and 11 June 2010 at the Univer- sity of New Hampshire's AIRMAP atmospheric monitoring station at Thompson Farm (THF2; 43.1078 ${ }^{\circ} \mathrm{N}, 70.9517^{\circ} \mathrm{W}$, $40 \mathrm{~m}$ elevation above sea level), located within a stand of mixed hardwood/pine forest $\sim 320 \mathrm{~m}$ from the original Thompson Farm monitoring station (THF) in rural Durham, $\mathrm{NH}$ (Talbot et al., 2005). At THF2 a $24 \mathrm{~m}$ observation tower extends above the surrounding forest canopy. Ambient air was drawn at $\sim 15001 \mathrm{~min}^{-1}$ at STP $(1013.25 \mathrm{mbar}$, $273.15 \mathrm{~K})$ through a PFA Teflon-lined aluminum manifold from the top of the tower using a Gast R7-Series regenerative blower (Gast Manufacturing, Inc., Benton Harbor, MI). Sub-samples were directed to a suite of trace gas analyzers, including the GC-FTD instrument, housed at the base of the tower. The temperature in the instrument room was maintained at $21.8 \pm 0.4^{\circ} \mathrm{C}$ during $3-10$ March and $19.6 \pm 0.4^{\circ} \mathrm{C}$ during 10-31 March.

\subsection{The GC-FTD instrument}

\subsubsection{Configuration}

Figure 1 shows a schematic of the GC-FTD instrument. The HCN calibration standard was a permeation tube source (VICI Metronics, Inc., Poulsbo, WA) contained in a glass chamber, imbedded in an aluminum block which was temperature-regulated at $30.0 \pm 1.5^{\circ} \mathrm{C}$ using an OMEGA CN76000 Series temperature controller (OMEGA Engineering, Inc., Stamford, CT). The NIST traceable gravimetric emission rate of the permeation tube was $122 \pm 5 \mathrm{ng} \mathrm{\textrm {min } ^ { - 1 }}$ at $30.0 \pm 0.5^{\circ} \mathrm{C}$. The $\mathrm{HCN}$ calibration gas was prepared in ultra-high purity (UHP) nitrogen $\left(\mathrm{N}_{2}\right)$ (Maine Oxy, Auburn, Maine) using an MKS type 1479A mass flow controller (MFC) (MKS Instruments, Inc., Andover, MA) coupled with an MKS type 247D digital readout. The calibration gas was further diluted in zero air to ambient levels $(0.1-1 \mathrm{ppbv})$ using a zero air generator (Apel-Riemer Environmental, 
Inc., Broomfield, $\mathrm{CO})$. The zero air generator's catalytic converter $\left(0.5 \%\right.$ palladium $(\mathrm{Pd})$ on alumina $\left.\left(\mathrm{Al}_{2} \mathrm{O}_{3}\right)\right)$ was operated at $425^{\circ} \mathrm{C}$.

Samples were dried at $-15^{\circ} \mathrm{C}$ in a $20 \mathrm{~cm} \times 0.3175 \mathrm{~cm}$ i.d. Silonite-coated loop (Entech Instruments, Inc., Simi Valley, CA) contained in an MMR model CC2202 Cryofocus System (MMR Technologies, Mountain View, CA; see Sive et al. (2005) for further details). Sample volumes of $250 \mathrm{STP} \mathrm{cm}^{3}$ were enriched at $-130{ }^{\circ} \mathrm{C}$ in a second $20 \mathrm{~cm} \times 0.3175 \mathrm{~cm}$ i.d. Silonite-coated loop (Entech Instruments, Inc.), packed with $1 \mathrm{~mm}$ diameter glass beads (Ohio Valley Specialty Co., Marietta, $\mathrm{OH}$ ), and contained in the Cryofocus System. Negligible HCN loss in the dehumidification loop was confirmed at temperatures as low as $-30^{\circ} \mathrm{C}$, which was the threshold temperature that could be achieved with the Cryofocus System. Trapping of HCN in the sample enrichment loop was confirmed to be quantitative for temperatures $\leq-110^{\circ} \mathrm{C}$. The sample flow rate during trapping was controlled at $200 \mathrm{STP} \mathrm{cm}^{3} \mathrm{~min}^{-1}$ by a downstream MFC (Aalborg Instruments and Controls, Inc., Orangeburg, NY), yielding a sample preconcentration time of $75 \mathrm{~s}$. Ambient air was sub-sampled from the main sample inlet manifold and supplied to the instrument using a single-head metal bellows pump (Senior Flexonics, Sharon, MA).

The Cryofocus System was incorporated in a custom built, fully automated sample acquisition system, designed after the prototype acquisition system that was described in detail by Sive et al. (2005). For measurement of HCN, an additional Valco 4-port switching valve (SV) (Valco Instruments Company, Inc., Houston, TX) was incorporated into the acquisition system to permit isolation of the sample enrichment loop between sample trapping and injection (Fig. 1). A Valco 8-port stream select valve (SSV) and downstream solenoid valves (ASCO, Novato, CA) directed the sample stream to the Cryofocus System for enrichment and to the GC for analysis, and they allowed the system to step between ambient air, the permeation source, and UHP helium $(\mathrm{He})$ during analysis, calibration, and purging, respectively, or to be isolated from the input gas streams while the sample and dehumidification loops cooled. Sample injections were performed in UHP He onto a $25 \mathrm{~m} \times 0.32 \mathrm{~mm}$ i.d., $5 \mu \mathrm{m}$ film thickness CP PoraBOND Q column (Varian, Inc., Palo Alto, CA) using a Valco 8-port SV. According to the manufacturer's specifications the CP PoraBOND Q column is a bonded porous polymer PLOT column exhibiting low bleed and high stability under exposure to water. A similar type of stationary phase, in combination with an FTD, was previously employed for separation and detection of cyanides from the headspace of blood samples (Seto et al., 1993).

The column and a Shimadzu FTD (Shimadzu Corporation, Columbia, MD) were housed in a Shimadzu model 2014c GC. The GC oven temperature program was $40^{\circ} \mathrm{C}$ for $7.5 \mathrm{~min}, 15^{\circ} \mathrm{C} \mathrm{min}{ }^{-1}$ to $150^{\circ} \mathrm{C}, 150^{\circ} \mathrm{C}$ for $4 \mathrm{~min}$. The FTD was operated at $200^{\circ} \mathrm{C}$ and a voltage of $80-90 \%$ relative to maximum. The carrier flow rate at the initial col- umn temperature was $21.6 \pm 0.2(1 \sigma) \mathrm{STP} \mathrm{cm}^{3} \mathrm{~min}^{-1}$. The makeup gas was UHP He at a flow rate of $8 \pm 1 \mathrm{~cm}^{3} \mathrm{~min}^{-1}$, while UHP hydrogen $\left(\mathrm{H}_{2}\right)$ and purified ambient air from an Aadco 737-series Pure Air Generator (Aadco, Cleves, $\mathrm{OH}$ ) were also supplied to the FTD at flow rates of $0.9 \pm 0.1 \mathrm{~cm}^{3}$ $\mathrm{min}^{-1}$ and $123 \pm 6 \mathrm{~cm}^{3} \mathrm{~min}^{-1}$, respectively. Activated charcoal/molecular sieve (13X) traps, prepared in-house and purchased from Ohio Valley, were used with all cylinders for further purification. Additionally, a Valco HP2 He purifier was used for the He carrier gas. Gas transfer lines were constructed of Silcosteel (Restek, Bellefonte, PA) and PFA 450 Teflon (E \& S Technologies, Inc., Chelmsford, MA).

\subsubsection{Overview of the FTD}

Thermionic detectors have not been commonly used for ambient air analysis. Previous applications of an FTD in the atmospheric sciences appear to be limited to measurement of ammonia by Yamamoto et al. $(1991,1994)$. Therefore, a brief description of the Shimadzu FTD (hereinafter abbreviated as FTD-2014c) and the FTD response mechanism is presented.

The FTD-2014c consists of a rubidium sulfate $\left(\mathrm{Rb}_{2} \mathrm{SO}_{4}\right)$ coated platinum (Pt) filament, enveloped by a cylindrical collector electrode mounted on the jet of a flame ionization detector (FID) (Arimoto et al., 1992; Shimadzu Corporation, 2004). An electrical current supplied to the filament by a power controller resistively heats the filament, thereby controlling the surface reactivity. The filament current can be adjusted by the operator, either directly or indirectly via the applied voltage.

The analytical signal in the FTD arises from the negative ion current generated by ionization of analytes at the surface of the heated filament. Application of a positive voltage bias to the collector facilitates transfer of ion current from the filament to the collector. Previous studies with thermionic detectors suggested that the heated filament induces a combination of gas-phase and surface ionization processes, the relative importance of which depends on the composition of the filament coating (Patterson, 1982; van de Weijer et al., 1988; Bombick and Allison, 1989). Incorporating alkali metal in the surface coating reduces the work function of the surface, and was empirically determined to yield sensitive, selective detection for $\mathrm{N}$ and phosphorous (P)-containing analytes (Bombick and Allison, 1989). The $\mathrm{H}_{2}$ and air supplied to the detector participate in the ionization chemistry and partially control selectivity and sensitivity (c.f., Bombick and Allison, 1989; Shimadzu Corporation, 2004). Impurities in the carrier and makeup gases further contribute to the detector background level.

It is known that FTD detectors exhibit loss of sensitivity with operation time (e.g., Colón and Baird, 2004). The rate of sensitivity decrease for the FTD-2014c used in the present work is proportional to the detector filament voltage (Shimadzu Corporation, 2004). Carrier and detector gas purity also partially govern the rate of sensitivity decrease 
Table 1. Operational protocol of the GC-FTD instrument.

\begin{tabular}{|c|c|c|c|c|c|c|c|c|}
\hline \multirow[b]{2}{*}{ Valve $^{\mathrm{a}}$} & \multicolumn{8}{|c|}{ Sample cycle stage, valve position } \\
\hline & 1. $\mathrm{Cool}^{\mathrm{b}}$ & 2. Preflush ${ }^{\mathrm{c}}$ & 3. Trap $^{c}$ & 4. Preflush ${ }^{\mathrm{d}}$ & 5. Trap ${ }^{d}$ & 6. Desorb $^{b}$ & 7. Inject ${ }^{\mathrm{d}}$ & 8. Bake \\
\hline SSV & $6,7,8$ & $1,3,4,5$ & $1,3,4,5$ & 2 & 2 & $6,7,8$ & 2 & 2 \\
\hline $\mathrm{SV}^{\mathrm{e}}$ & A & A & A & A & A & A & B & A \\
\hline$S V^{f}$ & $\mathrm{~A}$ & A & $\mathrm{A}$ & A & A & B & $\mathrm{A}$ & A \\
\hline V1 & closed & open & closed & open & closed & closed & closed & closed \\
\hline $\mathrm{V} 2$ & closed & closed & open & closed & open & closed & closed & closed \\
\hline V3 & closed & open & closed & open & closed & closed & closed & closed \\
\hline
\end{tabular}

${ }^{\mathrm{a}}$ As labeled in Fig. $1 .{ }^{\mathrm{b}} \mathrm{SSV}$ is in a dead end position. ${ }^{\mathrm{c}}$ Ambient or standard sample. ${ }^{\mathrm{d}}$ UHP He. ${ }^{\mathrm{e}}$ Eight-port SV. ${ }^{\mathrm{f}}$ Four-port SV.

(M. Smith, Shimadzu Corporation, personal communication, 2009). The loss of sensitivity of the FTD with time requires that the filament be periodically recoated. It is also feasible to replace the filament assembly entirely. A new coating of $\mathrm{Rb}_{2} \mathrm{SO}_{4}$ is applied to the heated filament by contact melting using a kit supplied by the manufacturer.

In the present work the FTD-2014c was operated using detector gas flows which conformed to the manufacturer's recommendations for selective detection of $\mathrm{N}$-containing analytes (Shimadzu Corporation, 2004). The FTD power controller voltage was set to a value that yielded maximum sensitivity to HCN. Under the operating conditions employed, we observed a maximum lifetime of $\sim 2$ months for a recoated filament. From our experience, detector sensitivity was recovered through 3 recoating cycles. Although we have not fully characterized the filament lifetime, our experience suggest that $>6$ months of semi-continuous $\mathrm{HCN}$ measurement should be achievable under our operating conditions without replacing the filament assembly entirely.

\subsubsection{Operational protocol}

Here we briefly describe the operational protocol of the instrument (please refer to Fig. 1 and Table 1). An analysis cycle was initiated when the sample dehumidification (T1) and enrichment (T2) loops cooled to $-30^{\circ} \mathrm{C}$ and $\leq-110^{\circ} \mathrm{C}$, respectively. Once the loops reached their initial cold trapping temperatures, the inlet lines were flushed with ambient air, zero air or calibration gas to condition them prior to trapping. Following conditioning, the gas stream was directed to the Cryofocus System where it was dehumidified in $\mathrm{T} 1$ and low-boiling constituents, including $\mathrm{HCN}$ and $\mathrm{CH}_{3} \mathrm{CN}$, were trapped in T2. The inlet lines were then flushed with UHP $\mathrm{He}$, after which the Cryofocus System was flushed with UHP $\mathrm{He}$ at a flow rate of $200 \mathrm{STP} \mathrm{cm}^{3} \mathrm{~min}^{-1}$ for $1 \mathrm{~min}$ to displace very low-boiling compounds (e.g., $\mathrm{N}_{2}, \mathrm{O}_{2}$ and ozone $\left(\mathrm{O}_{3}\right)$ ) from T2. Subsequently, T2 was isolated at the 4-port SV and heated in $\sim 1 \mathrm{~min}$ to $75^{\circ} \mathrm{C}$ to re-volatilize the trapped $\mathrm{HCN}$. When $\mathrm{T} 2$ reached $75^{\circ} \mathrm{C}$ the sample was injected in UHP He by sequentially switching the 8-port SV and the 4-port SV. After a 2 min injection, $\mathrm{T} 1$ and $\mathrm{T} 2$ were heated to $80^{\circ} \mathrm{C}$ and flushed with UHP He, at a flow rate of $\sim 300 \mathrm{STP} \mathrm{cm}^{3} \mathrm{~min}^{-1}$ for $5 \mathrm{~min}$ in preparation for the next sample. The instrument continuously stepped between sampling ambient air and the standard dilution system output, thereby measuring $\mathrm{HCN}$ in ambient air and in zero air (or zero air + calibration gas; see Sect. 2.2.4) during odd and even numbered sample cycles, respectively. Table 1 indicates the positions of the valves in Fig. 1 during each sample cycle stage. The measurement time resolution, which was largely governed by the cycle time of the Cryofocus System, was on average $21.4 \pm 0.5 \mathrm{~min}$ during March 2010. Valve actuation, the Cryofocus System temperature set points, and triggering of the GC were controlled by a program written in LabVIEW software (National Instruments Corporation, Austin, TX) and run from a personal computer (PC). Chromatograms were recorded on a second PC using Shimadzu Class-VP (7.4) data acquisition/analysis software.

\subsubsection{Calibration}

Instrument calibration was performed daily, typically between 13:00 and 18:00 local time (LT), by adding the HCN calibration gas (i.e., $\mathrm{HCN}$ in $\mathrm{UHP} \mathrm{N}_{2}$; Sect. 2.2.1) to the zero air generator output for $\sim 3.5 \mathrm{~h}$, yielding 5 replicate standard chromatograms for each calibration. The standard HCN mixing ratio was usually set to $0.25 \pm 0.01 \mathrm{ppbv}$. During two periods (7-15 and 18-26 March) the standard HCN mixing ratio was varied over three additional levels within the range $0.101 \pm 0.005$ to $0.75 \pm 0.04$ ppbv to quantify the system linearity; during these periods the standard mixing ratio was set to a level that differed from the common level of 0.25 ppbv typically every other day. Between each calibration, the zero air generator was isolated from the calibration gas to quantify the non-zero $\mathrm{HCN}$ background in the zero air diluent. Additionally, a qualitative $\mathrm{CH}_{3} \mathrm{CN}$ standard was analyzed to confirm the identification of the corresponding chromatographic peak.

\subsubsection{Data analysis}

Chromatograms were integrated manually using Shimadzu Class-VP software. For each ambient sample, the recorded 
raw chromatographic peak area, $A_{\mathrm{r}}$, was converted to a corresponding $\mathrm{HCN}$ volume mixing ratio (hereinafter abbreviated simply as mixing ratio), $\operatorname{VMR}(\mathrm{HCN})_{a}$, using the calibration standard chromatographic peak area, $A_{\mathrm{s}}$, the zero air background chromatographic peak area, $A_{\mathrm{b}}$, and the calibration standard $\mathrm{HCN}$ mixing ratio, $\mathrm{VMR}(\mathrm{HCN})_{\mathrm{s}}$ :

$\operatorname{VMR}(\mathrm{HCN})_{\mathrm{a}}=A_{\mathrm{r}} \cdot\left(\frac{\mathrm{VMR}(\mathrm{HCN})_{\mathrm{s}}}{A_{\mathrm{s}}-A_{\mathrm{b}}}\right)$

The bracketed term in Eq. (1), which represents the instrument sensitivity to $\mathrm{HCN}$, was calculated by interpolation between each daily set of calibration measurements at $\operatorname{VMR}(\mathrm{HCN})_{\mathrm{s}}=0.25 \pm 0.01 \mathrm{ppbv}$. For each calibration, the value of $A_{\mathrm{s}}$ was calculated by averaging over the 5 replicate standard measurements (Sect. 2.2.4), while the value of $A_{\mathrm{b}}$ was calculated by averaging over 5 blank measurements which bracketed the standards. The value of $\operatorname{VMR}(\mathrm{HCN})_{\mathrm{s}}$ was determined by the calibration standard emission rate, $e_{0}$ (ng $\min ^{-1}$ ), the $\mathrm{N}_{2}$ diluent flow rate through the permeation chamber, $f\left(\mathrm{~N}_{2}\right)$, the zero air generator standard inlet flow rate, $f_{i}$, and the zero air diluent flow rate, $f(\mathrm{ZA})$ :

$\operatorname{VMR}(\mathrm{HCN})_{\mathrm{s}}=e_{0} \cdot\left(\frac{22.40}{f\left(N_{2}\right) \cdot \mathrm{FW}}\right) \cdot\left(\frac{f_{i}}{f_{i}+f(\mathrm{ZA})}\right)$

In Eq. (2), flow rate units are liter $\mathrm{min}^{-1}$ (STP), 22.40 (STP liter $\mathrm{mol}^{-1}$ ) is the standard molar volume of $\mathrm{N}_{2}$ and $\mathrm{FW}$ is the molecular weight of $\mathrm{HCN}\left(27.03 \mathrm{~g} \mathrm{~mol}^{-1}\right)$.

\subsection{Supporting measurements}

To assist with the interpretation of the ambient $\mathrm{HCN}$ measurements (Sect. 3.2), we present concurrent measurements of several additional atmospheric parameters as discussed below.

Acetonitrile was measured with a high-sensitivity PTRMS instrument (Ionicon Analytik, Innsbruck, Austria) at mass to charge ratio $(\mathrm{m} / \mathrm{z})=42$ (Jordan et al., 2009). The PTR-MS drift tube temperature, pressure and voltage were $45^{\circ} \mathrm{C}, 2.00 \mathrm{mbar}$ and $600 \mathrm{~V}$, respectively. Acetonitrile was monitored together with 46 additional $\mathrm{m} / \mathrm{z}$, with dwell times of 1-20 s, yielding a sample cycle time of $\sim 6.5 \mathrm{~min}$. Under the sampling scheme employed, ambient air was monitored for $\sim 24 \mathrm{~h}$ ( 220 cycles), followed by $\sim 72 \mathrm{~min}$ (10 cycles) during which zero air was analyzed to quantify the instrument background. Zero air was generated by passing ambient air through a stainless steel tube packed with $\mathrm{Pt} / \mathrm{Al}_{2} \mathrm{O}_{3}$ beads $(0.5 \% \mathrm{Pt})$, heated to $600^{\circ} \mathrm{C}$. The PTR-MS sensitivity to $\mathrm{CH}_{3} \mathrm{CN}$ was $15.9 \mathrm{ncps} \mathrm{ppbv}^{-1}$ (ncps, normalized counts per second), based on calibrations with a high pressure cylinder (Apel-Reimer Environmental) containing $\mathrm{CH}_{3} \mathrm{CN}$ at the ppbv level with an accuracy of better than $5 \%$. The calibration gas was dynamically diluted to pptv-ppbv levels in zero air. The method detection limit (MDL), estimated as $2 \sigma$ of the instrument background response at $\mathrm{m} / \mathrm{z}=42$ was $0.031 \mathrm{ppbv}$.

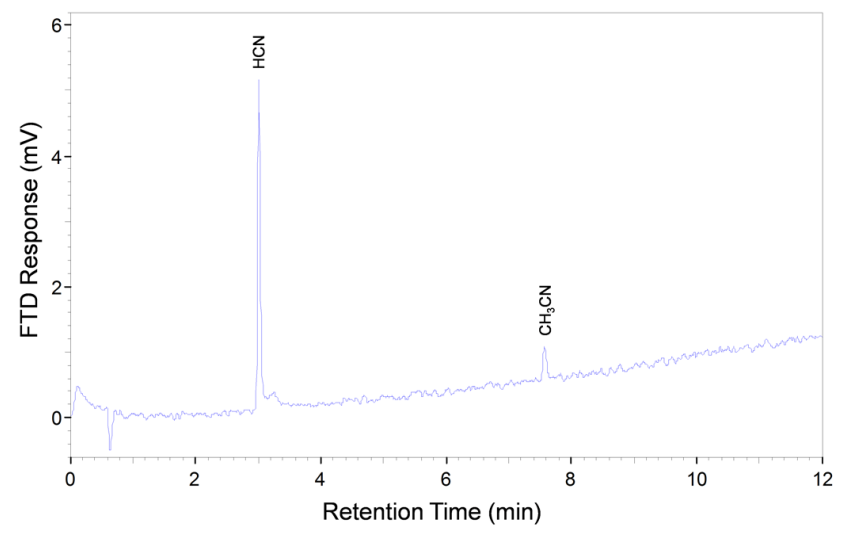

Fig. 2. An ambient chromatogram recorded with the GC-FTD instrument on 20 March, 16:35 LT during a period of relatively enhanced $\mathrm{HCN}$ mixing ratios. The small feature on the $\mathrm{HCN}$ peak tail represents a minor, reproducible peak splitting which depended on the desorption parameters of the Cryofocus System.

Ozone was measured by UV photometry at $254 \mathrm{~nm}$ using a Thermo Environmental Instruments (TEI) model 49C-PS analyzer (Mao and Talbot, 2004). The MDL and accuracy were $\sim 1$ ppbv.

Carbon monoxide (CO) was measured by IR absorbance at $4.6 \mu \mathrm{m}$ using a modified TEI model $48 \mathrm{CTL}$ analyzer (Mao and Talbot, 2004). The MDL was $40 \mathrm{ppbv}$ and the accuracy was $\sim 2 \%$.

Nitrogen dioxide photolysis frequency $\left(J\left(\mathrm{NO}_{2}\right)\right)$ was measured by filter radiometer (Griffin et al., 2007). The measurement uncertainty is $<5 \%$ based on factory calibration, though it is likely larger at high solar zenith angle.

The $\mathrm{O}_{3}, \mathrm{CO}$ and $J\left(\mathrm{NO}_{2}\right)$ measurements were made at $1 \mathrm{~min}$ time resolution and reduced to 10 -min averages for presentation here.

\section{Results and discussion}

\subsection{Instrument performance characteristics}

\subsubsection{Selectivity}

A chromatogram recorded with the GC-FTD instrument on 20 March, under conditions when the HCN mixing ratio was relatively enhanced, is shown in Fig. 2. Only two chromatographic peaks $\left(\mathrm{HCN}\right.$ and $\mathrm{CH}_{3} \mathrm{CN}$ ) were observed in ambient chromatograms recorded at THF2. The second peak, with a retention time of $\sim 7.5 \mathrm{~min}$ was attributed to $\mathrm{CH}_{3} \mathrm{CN}$ based on analysis of a $\mathrm{CH}_{3} \mathrm{CN}$ qualitative standard. Thus, the GCFTD instrument appeared to be highly selective for nitriles under the ambient conditions probed. Although quantitative analysis of $\mathrm{CH}_{3} \mathrm{CN}$ was not the goal of the present work, and was not thoroughly tested, it is anticipated that further development of the instrument will yield simultaneous quantitative measurements for both $\mathrm{HCN}$ and $\mathrm{CH}_{3} \mathrm{CN}$. 


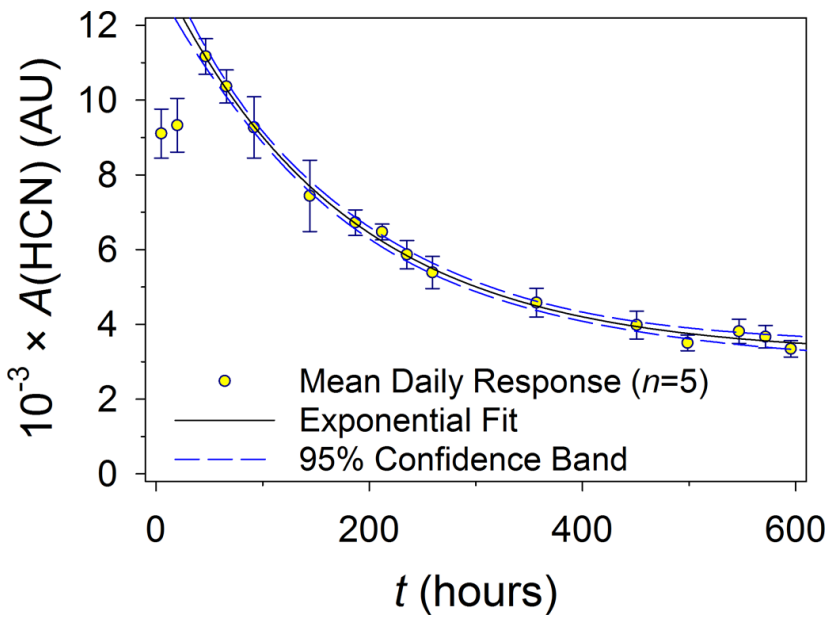

Fig. 3. Mean daily chromatographic peak areas (in area units; $n=5$ ) measured for standard HCN samples (VMR $=0.25 \pm 0.01 \mathrm{ppbv})$ analyzed during a period of continuous operation of the GC-FTD instrument during 3-31 March 2010. Error bars represent $1 \sigma$ of the mean peak area values and range from 3-13\%. Measurement times correspond with the elapsed time following instrument startup on 3 March $(t=0)$. Measurements were corrected for the nonzero background from the zero air generator. The fit represents a 3-parameter exponential function, which excluded measurements made during the initial $\sim 24 \mathrm{~h}$ warm-up period.

\subsubsection{Sensitivity}

A time series of the daily average HCN chromatographic peak area measured for each set of standard samples prepared at the 0.25 ppbv level during March 2010 is shown in Fig. 3. The values have been corrected for the non-zero HCN background from the zero air generator (Sect. 3.1.5). The time for each data point corresponds with the time difference between the daily median run time for the standards and the instrument start time, $t=0$, on 3 March. As illustrated in Fig. 3, the sensitivity of the FTD-2014c to HCN as measured with our system was well described by a 3-parameter exponential function of the form:

$y=a e^{-b t}+c$

The fit parameters for the data in Fig. 3 were: $a=(10.4 \pm 0.2) \times 10^{3}$ area units (AU), $b=(5.8 \pm 0.3) \times 10^{3} \mathrm{~h}^{-1}$ and $c=(3.2 \pm 0.1) \times 10^{3} \quad$ AU. The corresponding coefficient of determination, $r^{2}$, was 0.997 . The absolute value of the fit residuals was $<10 \%$. The fit in Fig. 3 excludes the first two sets of standard measurements made during the initial $\sim 24 \mathrm{~h}$ warm-up period, which followed an extended power outage at THF2. On intermediate timescales $(\sim 1-2$ weeks $)$ the sensitivity trend was nearly linear. Although the loss of sensitivity demonstrated in Fig. 3 is undesirable, it could be accurately accounted for by calibration.

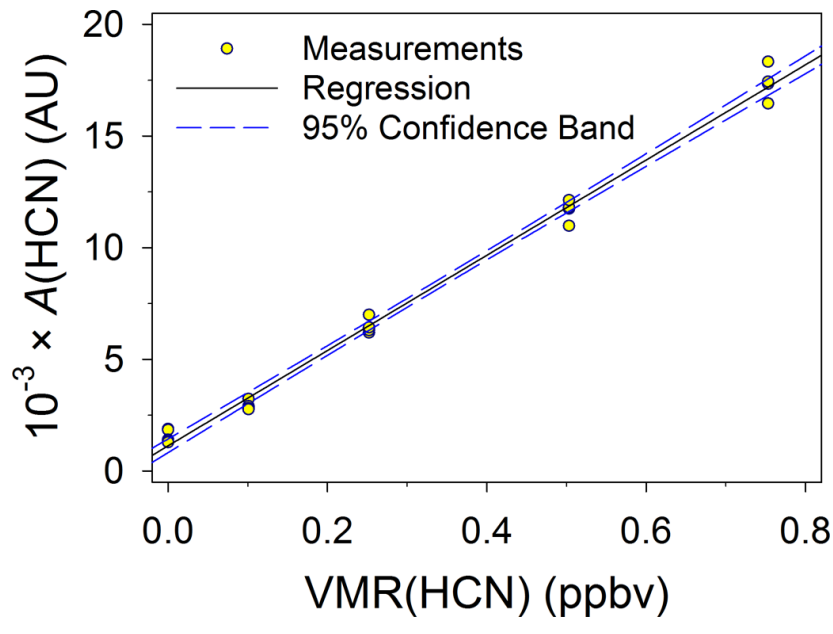

Fig. 4. A calibration curve constructed from de-trended standard and blank measurements made during 18-26 March 2010. Each group of data points at $\mathrm{VMR}(\mathrm{HCN})>0$ ppbv represents the 5 replicate standard measurements from a single daily calibration; the chromatographic peak areas have not been corrected for the corresponding blanks. The group of data points at $\mathrm{VMR}(\mathrm{HCN})=0 \mathrm{ppbv}$ represents the mean values of the 5 replicate blanks measured in conjunction with each calibration. The group of data points at $\operatorname{VMR}(\mathrm{HCN})=0.25 \mathrm{ppbv}$ corresponds with the "reference" calibration on 18 March.

\subsubsection{Precision}

The error bars in Fig. 3 represent $1 \sigma$ of the mean daily peak area values $(n=5)$ and range from $3-13 \%$, with a mean value of $7 \%$. The measurement precision did not depend significantly on the standard mixing ratio or detector sensitivity over the range of conditions tested. For example, in the course of multi-point calibration measurements performed during 18-26 March (Sect. 3.1.4), the precision ranged from $4-6 \%$. The precision of the zero air generator background was somewhat poorer. For the blank measurements corresponding with the calibration data shown in Fig. 3, the mean precision was $12 \%$.

\subsubsection{Linearity}

A multipoint calibration curve constructed from calibration measurements made during 18-26 March is shown in Fig. 4. The non-zero measurements of the zero air generator are included in the calibration plot. The measurements presented in Fig. 4 have been "de-trended" (i.e., corrected for change in detector sensitivity (Sect. 3.1.2)) by normalizing to the sensitivity measured for the calibration on 18 March at $\operatorname{VMR}(\mathrm{HCN})_{\mathrm{s}}=0.25 \pm 0.01 \mathrm{ppbv}$. The calculation can be 
described by Eq. (4):

$$
\begin{aligned}
& A^{\text {de-trended }} \\
& \quad=A \cdot\left(\frac{\mathrm{VMR}(\mathrm{HCN})_{\mathrm{s}}}{\left(A_{\mathrm{s}}-A_{\mathrm{b}}\right)^{\text {interpolated }}}\right) \cdot\left(\frac{\left(A_{\mathrm{s}}-A_{\mathrm{b}}\right)^{\text {reference }}}{\mathrm{VMR}(\mathrm{HCN})_{\mathrm{s}}}\right) \\
& \quad=A \cdot\left(\frac{\left(A_{\mathrm{s}}-A_{\mathrm{b}}\right)^{\text {reference }}}{\left(A_{\mathrm{s}}-A_{\mathrm{b}}\right)^{\text {interpolated }}}\right),
\end{aligned}
$$

where $A$ is the measured chromatographic peak area and $A^{\text {de-trended }}$ is the peak area corrected for sensitivity drift. The first bracketed term in Eq. (4) represents the instrument sensitivity (Sect. 2.2.5) interpolated to the time at which the value of $A$ was measured, the second the instrument sensitivity measured for the "reference" calibration at $\operatorname{VMR}(\mathrm{HCN})_{\mathrm{s}}=0.25 \pm 0.01 \mathrm{ppbv}$ (i.e., the $18 \mathrm{March}$ calibration for the data shown in Fig. 4).

The instrument showed good linearity on the calibration scale employed. A least squares regression analysis yielded a slope and intercept of $(21.3 \pm 0.3) \times 10^{3} \mathrm{AU}_{\mathrm{ppbv}}^{-1}$ and $(1.1 \pm 0.1) \times 10^{3} \mathrm{AU}$, respectively, with $r^{2}=0.994$. The MDL was estimated as $3 \sigma_{\mathrm{b}} / m=0.021 \mathrm{ppbv}$, where $\sigma_{\mathrm{b}}$ is the standard deviation of the intercept and $m$ is the slope of the calibration plot, as derived from least squares analysis (Lavagnini and Magno, 2007). The results of the multilevel calibrations performed during 7-15 and 18-26 March were in good quantitative agreement. When normalized to the instrument sensitivity on 18 March, the slope of the calibration curve for the 7-15 March data was within $10 \%$ of that for the 18-26 March data $\left(r^{2}=0.995\right)$. During the period from 7-18 March the instrument sensitivity decreased by $\sim 50 \%$. Thus, the instrument linearity does not appear to have been significantly affected by sensitivity drift.

\subsubsection{Zero air background}

As indicated above, the HCN level in the zero air diluent was non-zero. During 3-31 March, the ratio $A_{\mathrm{b}} / A_{\mathrm{s}}$ for the 0.25 ppbv standards ranged from $0.20-0.29$ with a mean value of $0.24 \pm 0.03$. By comparison, the variability in the ambient $\mathrm{HCN}$ mixing ratio was significantly greater than that in the zero air background. For instance, the range of the ratio $A_{\mathrm{b}} / A_{\mathrm{a}}$ was $0.18-0.55$ with a mean value of $0.3 \pm 0.1$. This suggests that incomplete chemical conversion of $\mathrm{HCN}$ within the catalytic converter may only partly have governed the background HCN level in the zero air diluent.

The dependence of the background signal on the zero air generator operating parameters was not investigated, though it is a goal for future work with this system to do so. We sought to calibrate the instrument at a level which most closely matched the typical ambient $\mathrm{HCN}$ mixing ratio. Having demonstrated the instrument linearity (Sect. 3.1.4), we could minimize the relative significance of the background level in the future by using a slightly higher standard mixing ratio for daily single-point calibrations.

\subsubsection{Accuracy}

The accuracy of the HCN measurements is governed by the individual accuracies of the permeation chamber temperature $\left( \pm 1.5^{\circ} \mathrm{C}\right)$ and the standard dilution system flow rates $(\leq \pm 5 \%)$. The accuracy of the permeation chamber temperature was slightly poorer than that of the chamber in which the $\mathrm{HCN}$ emission rate was calibrated $\left( \pm 0.5^{\circ} \mathrm{C}\right)$; therefore, it is likely that the uncertainty of the $\mathrm{HCN}$ emission rate is greater than the value of $\pm 5 \mathrm{ng} \mathrm{min}^{-1}( \pm 4 \%)$ specified by the manufacturer. For instance, at $30^{\circ} \mathrm{C}$ the $\mathrm{HCN}$ vapor pressure varies by $\pm 2 \%$ and $\pm 6 \%$ for temperature differences of $\pm 0.5^{\circ} \mathrm{C}$ and $\pm 1.5^{\circ} \mathrm{C}$, respectively, based on published vapor pressure data (Lide, 2008). The accuracy of the HCN emission rate in our permeation chamber was estimated using the emission rate temperature dependence specified by the manufacturer (VICI Metronics, Inc., 2004):

$\log \left(e_{\Delta T}\right)=\log \left(e_{0}\right)+\alpha \cdot(\Delta T)$

where $\Delta T$ is the permeation chamber temperature accuracy, $e_{\Delta T}$ is the emission rate at the calibration temperature $\pm \Delta T$ (e.g., $30.0 \pm 1.5^{\circ} \mathrm{C}$ ), and $\alpha$ is the permeation source temperature coefficient $(0.034$ for our permeation tube). Based on the value of $e_{\Delta T}$ calculated using Eq. (5) (e.g., $137 \mathrm{ng} \mathrm{min}^{-1}$ at $31.5^{\circ} \mathrm{C}$ ) we estimated the accuracy of the $\mathrm{HCN}$ emission rate to be $\pm 12 \%$.

Propagating the estimated accuracy of the HCN emission rate and the individual flow rate accuracies through the $\mathrm{HCN}$ VMR calculation (Eq. 2) yields an estimated overall accuracy in the reported mixing ratios of $\pm 15 \%$. We do not have an independent measure of the overall accuracy of the instrument at this time. However, cross-calibration of the HCN standard emission rate in-situ using a multi-pass IR instrument has been demonstrated elsewhere (Crounse et al., 2009).

\subsection{Ambient air analysis}

We present here the subset of ambient $\mathrm{HCN}$ measurements made with the GC-FTD instrument during 3-31 March 2010. Figure 5a shows a time series of the ambient HCN mixing ratio, derived from the calibration data in Fig. 3. Also included in Fig. 5a are the PTR-MS $\mathrm{CH}_{3} \mathrm{CN}$ mixing ratios. Figure $5 \mathrm{~b}$ presents the $10 \mathrm{~min}$ averaged mixing ratios of $\mathrm{CO}$ and $\mathrm{O}_{3}$. In both panes of Fig. 5, a time series of 10 min averaged $J\left(\mathrm{NO}_{2}\right)$, normalized to the maximum value of $5.6 \times 10^{-3} \mathrm{~s}^{-1}$ recorded during March, delineates daytime and nighttime periods and provides a relative measure of solar actinic flux.

The range of the ambient $\mathrm{HCN}$ mixing ratios was 0.15 $1.0( \pm 15 \%)$ ppbv, with a mean and median of $0.36 \pm 0.16$ and $0.34 \mathrm{ppbv}$, respectively. Our measurements are not directly comparable to most measurements reported previously in the middle and upper troposphere. It appears that the mean $\mathrm{HCN}$ mixing ratio measured in the planetary boundary layer (PBL) in the $0-2 \mathrm{~km}$ altitude bin during early spring in the 


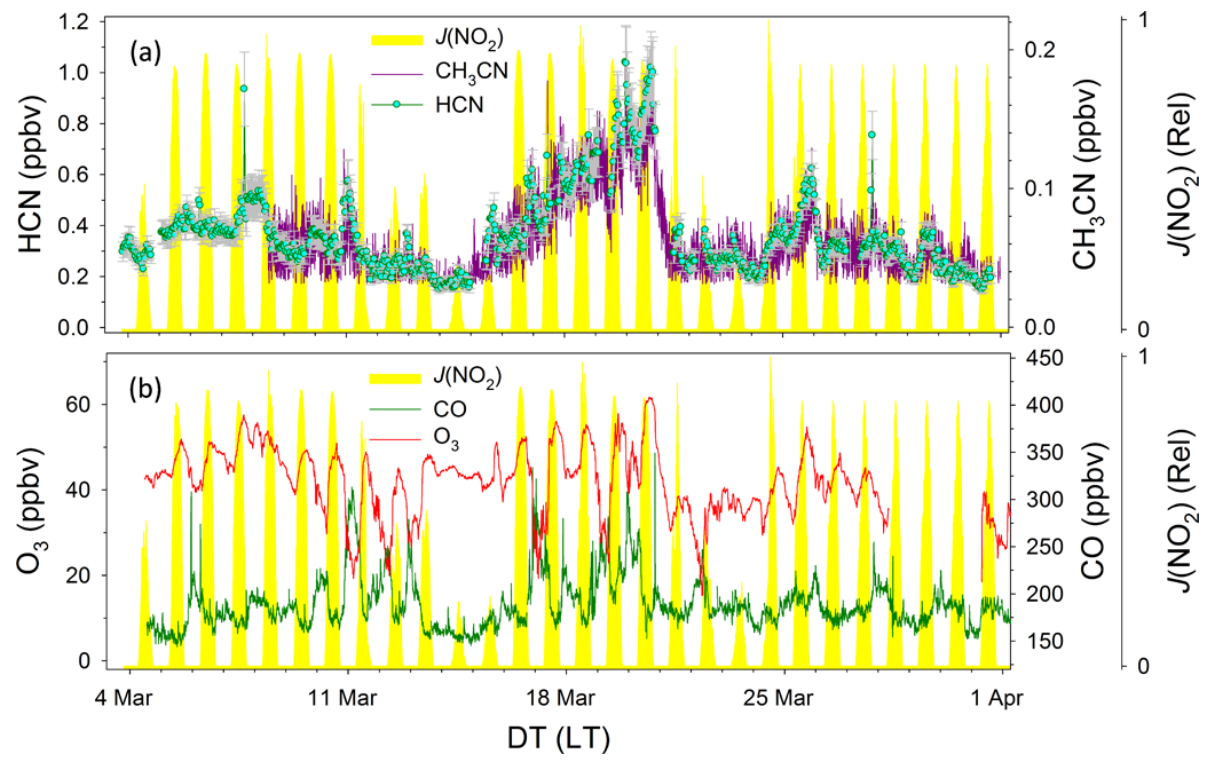

Fig. 5. (a) Time series of ambient $\mathrm{HCN}$ VMR measured at THF2 during 3-31 March 2010 with the GC-FTD instrument together with $\mathrm{CH}_{3} \mathrm{CN}$ VMR measured by PTR-MS. (b) Time series of $\mathrm{O}_{3}$ and CO VMR (10-min averages). Error bars on the HCN measurements represent the estimated overall measurement accuracy of $\pm 15 \%$. A time series of $J\left(\mathrm{NO}_{2}\right)$ (10-min averages) is shown to delineate daytime and nighttime periods. Note that the filter radiometer was removed from THF2 for calibration on 25 March; therefore, the $J\left(\mathrm{NO}_{2}\right)$ values for the period 25 March 09:05 LT to 1 April 06:00 LT represent the median profile for the period 17-24 March.

western Pacific region was lower at $0.23 \pm 0.16 \mathrm{ppbv}$ (Singh et al., 2003). Taking the period of 14-15 March to be representative of the background troposphere, corresponding with minima in the levels of the nitriles and $\mathrm{CO}$, yielded an average $\mathrm{HCN}$ mixing ratio of $0.20 \pm 0.04$ ppbv; by comparison an average level of $0.21 \pm 0.05 \mathrm{ppbv}$ was measured between $0-12 \mathrm{~km}$ in the western Pacific region under relatively clean conditions (Singh et al., 2003). Measurements of HCN at a suburban site in Boston, MA during October 2007 ranged from $<0.1$ to $\sim 0.6 \mathrm{ppbv}$ and yielded a background $\mathrm{HCN}$ mixing ratio of $\sim 0.2 \mathrm{ppbv}$ (Knighton et al., 2009). A significant trend in tropospheric $\mathrm{HCN}$ levels is not anticipated over the past decade, based on available long-term records (Rinsland et al., 2007).

Figure 5a demonstrates that $\mathrm{HCN}$ and $\mathrm{CH}_{3} \mathrm{CN}$ were highly correlated at THF2 during the measurement period. Similar concurrent measurements of these two gases have not previously been reported from a surface atmospheric observing station. Since $\mathrm{HCN}$ and $\mathrm{CH}_{3} \mathrm{CN}$ are thought to share common primary BB sources, a significant correlation between their levels in ambient air is to be expected. Singh et al. (2003) observed a slightly non-linear correlation between $\mathrm{HCN}$ and $\mathrm{CH}_{3} \mathrm{CN}$ measurements in the western Pacific free troposphere, which included influences from $\mathrm{SE}$ Asian BB plumes. A strong linear $\mathrm{CH}_{3} \mathrm{CN} / \mathrm{HCN}$ correlation was reported from airborne measurements made over the Mexico City area, which included fresh BB plumes (Crounse et al., 2009).
A clear, consistent relationship between the abundances of the nitriles and that of $\mathrm{CO}$, a general combustion tracer, was not evident at THF2 during the measurement period. For instance, the nitriles appeared to be correlated with $\mathrm{CO}$ on several nights (e.g., 10-11 and 25-26 March) and all three compounds attained minimum levels during 14 15 March; however, the persistent buildup of the nitriles between 16 and 20 March and their subsequent rapid decline during 20 March appeared to be largely independent of CO during the same time period.

Several previous studies have highlighted the role of the nocturnal boundary layer in regulating trace gas abundances in the region encompassing the Thompson Farm observing stations (Mao and Talbot, 2004; Talbot et al., 2005; Mao et al., 2006; White et al., 2008; Ambrose et al., 2010). Levels of trace gases with local emission sources (e.g., CO) are enhanced during nighttime beneath the inversion layer; conversely, depletion is observed for trace gases with chemical sinks at the surface (e.g., $\mathrm{O}_{3}$ ). During daytime, when surface warming induces turbulent decay of the nocturnal inversion, trace gases in the overlying residual layer are mixed down to the surface, leading to dilution of trace gases with surface sources and replenishment of trace gases with surface sinks. The influence of the nocturnal inversion layer on $\mathrm{O}_{3}$ and $\mathrm{CO}$ levels at THF2 was evident during several days in March, including 9-13 and 16-20 (Fig. 5b). The correlated enhancements in nitriles and $\mathrm{CO}$ on the nights of $10-11$ and 2526 March suggest a common emission source for these compounds in the region surrounding THF2 during those nights. 
However, it appears that HCN levels were only weakly influenced by the PBL dynamics during most of March. Thus, the increasing HCN levels observed during 16-20 March appeared not to have been isolated to the surface layer but rather to have been consistent throughout the tropospheric mixed layer, consistent with a large-scale, BB influence. In order to fully explain the observed variations in the nitriles, further analysis of the data is necessary, though it is beyond the scope of this work.

\section{Summary}

A GC-FTD instrument was developed for measurement of $\mathrm{HCN}$ in the lower atmosphere and was deployed for ambient air analysis at the AIRMAP atmospheric monitoring station THF2 for a 4 month period during January-June 2010. The FTD was chosen for its superior sensitivity and selectivity for N-containing organic compounds. A low bleed, robust porous polymer PLOT column was chosen for analyte separation. Ambient samples were pre-concentrated on a glass bead-packed Silonite-coated stainless steel loop in a cryogen-free cooler. Quantitative calibration of the $\mathrm{HCN}$ measurements was performed by dynamic dilution of a permeation tube standard in a near-ambient matrix. The measurement time resolution was $\sim 20 \mathrm{~min}$, with a sample preconcentration time of $\sim 75 \mathrm{~s}$ for a $250 \mathrm{STP} \mathrm{cm}^{3}$ sample volume. Measurements made during 3-31 March were used to illustrate the performance characteristics of the instrument. The following conclusions were drawn:

The instrument's selectivity for HCN was excellent. Only one additional compound was observed in the chromatograms of the ambient air samples analyzed at THF2. This compound was identified as $\mathrm{CH}_{3} \mathrm{CN}$ based on the retention time of a qualitative standard. With further characterization and proper calibrations, the instrument will yield concurrent $\mathrm{CH}_{3} \mathrm{CN}$ measurements.

Although the FTD was sufficiently sensitive to HCN for quantitative analysis, the sensitivity decreased with time as is characteristic of this type of detector. Although undesirable from a long-term monitoring perspective, the sensitivity trend was accurately quantified by the daily calibration scheme employed. For long-term operation in the field, periodic recoating or replacement of the FTD filament is required. Under our operating conditions a maximum measurement interval of $\sim 2$ months was achieved between successive recoatings, which should at least yield maintenance-free operation on typical field campaign timescales.

The instrument linearity was excellent over a standard mixing ratio range of $0.10-0.75 \mathrm{ppbv}( \pm 5 \%)$, which mostly bracketed ambient levels. The measurement precision was $<10 \%$, the overall accuracy $\pm 15 \%$ and the instrument MDL 0.021 ppbv. With independent methods under development for ground-based HCN measurement (e.g., PTR-MS) side-by-side intercomparison exercises should be feasible in the future.

The range of the ambient $\mathrm{HCN}$ mixing ratios was 0.15 $1.0 \mathrm{ppbv}( \pm 15 \%)$, with a mean value of $0.36 \pm 0.16 \mathrm{ppbv}$. The average mixing ratio appeared to be higher than observed previously during early spring via aircraft GCreduction gas detector (RGD) measurements in the PBL over the western Pacific (Singh et al., 2003). However, the estimated background level at THF2 appeared to agree better with the western Pacific tropospheric background levels and with background levels derived from ground-based PTR-MS measurements made at a suburban site in the northeastern US during fall (Knighton et al., 2009). Strong correlation was observed between the GC-FTD HCN measurements and simultaneous $\mathrm{CH}_{3} \mathrm{CN}$ measurements made by PTR-MS, in agreement with our understanding that both nitriles share a common primary biomass burning source to the atmosphere. A preliminary analysis of the nitrile measurements, together with measurements of $\mathrm{O}_{3}$ and $\mathrm{CO}$ suggests that local combustion was a minor, episodic source of HCN at THF2 during March. Additionally, a significant buildup of the nitriles from 16-20 March is consistent with a large-scale, BB influence on atmospheric composition at THF2, which was not clearly evident from the $\mathrm{CO}$ measurements.

Results from the first field deployment of the GC-FTD instrument suggest that the instrument has the capability to measure $\mathrm{HCN}$ in the PBL with high sensitivity, selectivity and precision. Future deployment of this type of instrument should yield valuable information regarding (1) the temporal variability and budget of $\mathrm{HCN}$ in the lower atmosphere and (2) the influence of biomass combustion on atmospheric composition at Earth's surface.

Acknowledgements. Financial support for this work was provided to UNH through grant \#NA07OAR4600514 from the Office of Oceanic and Atmospheric Research at the National Oceanic and Atmospheric Administration. The authors thank Don Troop for writing the instrument's control program in LabVIEW, Eric Scheuer for providing the permeation system used for standard preparation, Kevan Carpenter and Cheryl Parker for assistance with integrating the GC-FTD instrument into THF2, and Gary Weisman for providing $\mathrm{CH}_{3} \mathrm{CN}$ for analysis. Additionally, the authors thank two anonymous reviewers for their comments on the original version of this manuscript.

Edited by: D. Riemer

\section{References}

Aikman, K., Bergman, D., Ebinger, J., and Seigler, D.: Variation of cyanogenesis in some plant species of the Midwestern United States, Biochem. Syst. Ecol., 24, 637-645, 1996.

Ambrose, J. L., Haase, K., Russo, R. S., Zhou, Y., White, M. L., Frinak, E. K., Jordan, C., Mayne, H. R., Talbot, R., and Sive, B. C.: A comparison of GC-FID and PTR-MS toluene measure- 
ments in ambient air under conditions of enhanced monoterpene loading, Atmos. Meas. Tech., 3, 959-980, doi:10.5194/amt-3959-2010, 2010.

Arimoto, H., Ozaki, K., Shiomi, K., and Hamada, N.: Response characteristics of flame thermionic detector to sulfur compounds, Anal. Sci., 8, 173-177, 1992.

Baum, M., Moss, J. A., Pastel, S. H., and Poskrebyshev, G. A.: Hydrogen cyanide exhaust emissions from in-use motor vehicles, Environ. Sci. Technol., 41, 857-862, 2007.

Becidan, M., Skreiberg, Ø., and Hustad, J. E.: $\mathrm{NO}_{\mathrm{x}}$ and $\mathrm{N}_{2} \mathrm{O}$ precursors $\left(\mathrm{NH}_{3}\right.$ and $\left.\mathrm{HCN}\right)$ in pyrolysis of biomass residues, Energ. Fuel., 21, 1173-1180, 2007.

Blake, R. S., Monks, P. S., and Ellis, A. M.: Proton-Transfer Reaction Mass Spectrometry, Chem. Rev., 109, 861-896, 2009.

Bombick, D. D. and Allison, J.: Investigation into the response mechanism of the gas-chromatographic thermionic ionization detector. 1. Mass-spectral studies, J. Chromatogr. Sci., 27, 612619,1989

Christian, T. J., Kleiss, B., Yokelson, R. J., Holzinger, R., Crutzen, P. J., Hao, W. M., Shirai, T., and Blake, D. R.: Comprehensive laboratory measurements of biomass-burning emissions: 2. First intercomparison of open-path FTIR, PTRMS, and GC-MS/FID/ECD, J. Geophys. Res., 109, D02311, doi:10.1029/2003JD003874, 2004.

Cicerone, R. J. and Zellner, R.: The atmospheric chemistry of hydrogen cyanide (HCN), J. Geophys. Res., 88, 10689-10696, 1983.

Coffey, M. T., Mankin, W. G., and Cicerone, R. J.: Spectroscopic detection of stratospheric hydrogen cyanide, Science, 214, 333335, 1981.

Colón, L. A. and Baird, L. J.: Detectors in modern gas chromatography, in: Modern Practice of Gas Chromatography, edited by: Grob, R. L. and Barry, E. F., John Wiley and Sons, Inc., Hoboken, New Jersey, USA, 277-337, 2004.

Crounse, J. D., McKinney, K. A., Kwan, A. J., and Wennberg, P. O.: Measurement of gas-phase hydroperoxides by chemical ionization mass spectrometry, Anal. Chem., 78, 6726-6732, 2006

Crounse, J. D., DeCarlo, P. F., Blake, D. R., Emmons, L. K., Campos, T. L., Apel, E. C., Clarke, A. D., Weinheimer, A. J., McCabe, D. C., Yokelson, R. J., Jimenez, J. L., and Wennberg, P. O.: Biomass burning and urban air pollution over the Central Mexican Plateau, Atmos. Chem. Phys., 9, 4929-4944, doi:10.5194/acp-9-4929-2009, 2009.

Custer, T. G., Kato, S., Fall, R., and Bierbaum, V. M.: Negative ion mass spectrometry and the detection of carbonyls and $\mathrm{HCN}$ from clover, Geophys. Res. Lett., 27, 3849-3852, 2000.

Custer, T. G., Kato, S., Fall, R., and Bierbaum, V. M.: Negativeion CIMS: analysis of volatile leaf wound compounds including HCN, Int. J. Mass Spectrom., 223-224, 427-446, 2003.

Dagaut, P., Glarborg, P., and Alzueta, M. U.: The oxidation of hydrogen cyanide and related chemistry, Prog. Energy Combust. Sci., 34, 1-46, 2008.

Fall, R., Custer, T. G., Kato, S., and Bierbaum, V. M.: New directions: The biogenic acetone-HCN connection, Atmos. Environ., 35, 1713-1714, 2001 .

Glarborg, P., Jensen, A. D., and Johnsson, J. E.: Fuel nitrogen conversion in solid fuel fired systems, Prog. Energy Combust. Sci., 29, 89-113, 2003.
Goode, J. G., Yokelson, R. J., Ward, D. E., Susott, R. A., Babbitt, R. E., Davies, M. A., and Hao, W. M.: Measurements of excess $\mathrm{O}_{3}, \mathrm{CO}_{2}, \mathrm{CO}, \mathrm{CH}_{4}, \mathrm{C}_{2} \mathrm{H}_{4}, \mathrm{C}_{2} \mathrm{H}_{2}, \mathrm{HCN}, \mathrm{NO}, \mathrm{NH}_{3}, \mathrm{HCOOH}$, $\mathrm{CH}_{3} \mathrm{OOH}, \mathrm{HCHO}$, and $\mathrm{CH}_{3} \mathrm{OH}$ in 1997 Alaskan biomass burning plumes by airborn Fourier transform infrared spectroscopy (AFTIR), J. Geophys. Res., 105, 22147-22166, 2000.

Griffin, R. J., Beckman, P. J., Talbot, R. W., Sive, B. C., and Varner, R. K.: Deviations from ozone photostationary state during the International Consortium for Atmospheric Research on Transport and Transformation 2004 campaign: Use of measurements and photochemical modeling to assess potential causes, J. Geophys. Res., 112, D10S07, doi:10.1029/2006JD007604, 2007.

Holzinger, R., Warneke, C., Hansel, A., Jordan, A., and Lindinger, W.: Biomass burning as a source of formaldehyde, acetaldehyde, methanol, acetone, acetonitrile, and hydrogen cyanide, Geophys. Res. Lett., 26, 1161-1164, 1999.

Hurst, D. F., Griffith, D. W. T., Carras, J. N., Williams, D. J., and Fraser, P. J.: Measurements of trace gases emitted by Australian savanna fires during the 1990 dry season, J. Atmos. Chem., 18, 33-65, 1994a.

Hurst, D. F., Griffith, D. W. T., and Cook, G. D.: Trace gas emissions from biomass burning in tropical Australian savannas, J. Geophys. Res., 99, 16441-16456, 1994b.

Johnson, W. R. and Kang, J. C.: Mechanisms of hydrogen cyanide formation from the pyrolysis of amino acids and related compounds, J. Org. Chem., 36, 189-192, 1971.

Jordan, C., Fitz, E., Hagan, T., Sive, B., Frinak, E., Haase, K., Cottrell, L., Buckley, S., and Talbot, R.: Long-term study of VOCs measured with PTR-MS at a rural site in New Hampshire with urban influences, Atmos. Chem. Phys., 9, 4677-4697, doi:10.5194/acp-9-4677-2009, 2009.

Karlsson, H. L.: Ammonia, nitrous oxide and hydrogen cyanide emissions from five passenger vehicles, Sci. Total Environ., 334 335, 125-132, 2004.

Kleinböhl, A., Toon, G. C., Sen, B., Blavier, J.-F. L., Weisenstein, D. K., Strekowski, R. S., Nicovich, J. M., Wine, P. H., and Wennberg, P. O.: On the stratospheric chemistry of hydrogen cyanide, Geophys. Res. Lett., 33, L11806, doi:10.1029/2006GL026015, 2006.

Knighton, W. B., Fortner, E. C., Midey, A. J., Viggiano, A. A., Herndon, S. C., Wood, E. C., and Kolb, C. E.: HCN detection with a proton transfer reaction mass spectrometer, Int. J. Mass. Spectrom., 283, 112-121, 2009.

Lavagnini, I. and Magno, F.: A statistical overview on univariate calibration, inverse regression, and detection limits: Application to gas chromatography/mass spectrometry technique, Mass Spectrom. Rev., 26, 1-18, 2007.

Li, Q., Jacob, D. J., Bey, I., and Yantosca, R. M.: Atmospheric hydrogen cyanide $(\mathrm{HCN})$ : biomass burning source, ocean sink?, Geophys. Res. Lett., 27, 357-360, 2000.

Li, Q., Jacob, D. J., Yantosca, R. M., Heald, C. L., Singh, H. B., Koike, M., Zhao, Y., Sachse, G. W., and Streets, D. G.: A global three-dimensional model analysis of the atmospheric budget of $\mathrm{HCN}$ and $\mathrm{CH}_{3} \mathrm{CN}$ : Constraints from aircraft and ground measurements, J. Geophys. Res., 108, 8827, doi:10.1029/2002JD003075, 2003.

Li, Q., Palmer, P. I., Pumphrey, H. C., Bernath, P., and Mahieu, E.: What drives the observed variability of $\mathrm{HCN}$ in the troposphere and lower stratosphere?, Atmos. Chem. Phys., 9, 8531- 
8543, doi:10.5194/acp-9-8531-2009, 2009.

Lide, D. R. (Ed.): CRC Handbook of Chemistry and Physics, 88th Edn., CRC Press, Boca Raton, Florida, USA, 2008.

Lobert, J. M., Scharffe, D. H., Kuhlbusch, T. A., Seuwen, R., and Crutzen, P. J.: Experimental evaluation of biomass burning emissions: Nitrogen and carbon containing compounds, in: Global Biomass Burning: Atmospheric, Climatic, and Biospheric Implications, edited by: Levine, J. S., MIT Press, Cambridge, Massachusetts, USA, 289-304, 1991.

Mahieu, E., Zander, R., Delbouille, L., Demoulin, P., Roland, G., and Servais, C.: Observed trends in total vertical column abundances of atmospheric gases from IR solar spectra recorded at the Jungfraujoch, J. Atmos. Chem., 28, 227-243, 1997.

Mao, H. and Talbot, R.: $\mathrm{O}_{3}$ and $\mathrm{CO}$ in New England: Temporal variations and relationships, J. Geophys. Res., 109, D21304, doi:10.1029/2004JD004913, 2004.

Mao, H., Talbot, R., Nielsen, C., and Sive, B.: Controls on methanol and acetone in marine and continental atmospheres, Geophys. Res. Lett., 33, L02803, doi:10.1029/2005GL024810, 2006.

Patterson, P. L.: New uses of thermionic ionization detectors in gas chromatography, Chromatographia, 16, 107-111, 1982.

Poulton, J. E. and Li, C. P.: Tissue level compartmentation of (R)-amygdalin and amygdalin hydrolase prevents large-scale cyanogenisis in undamaged Prunus seeds, Plant. Physiol., 104, 29-35, 1994.

Rinsland, C. P., Mahieu, E., Zander, R., Demoulin, P., Forrer, J., and Buchmann, B.: Free tropospheric $\mathrm{CO}, \mathrm{C}_{2} \mathrm{H}_{6}$, and $\mathrm{HCN}$ above central Europe: Recent measurements from the Jungfraujoch station including the detection of elevated columns during 1998, J. Geophys. Res., 105, 24235-24249, 2000.

Rinsland, C. P., Goldman, A., Hannigan, J. W., Wood, S. W., Chiou, L. S., and Mahieu, E.: Long-term trends of tropospheric carbon monoxide and hydrogen cyanide from analysis of high resolution infrared solar spectra, J. Quant. Spectrosc. Ra., 104, 40-51, 2007.

Schneider, J., Bürger, V., and Arnold, F.: Methyl cyanide and hydrogen cyanide measurements in the lower stratosphere: Implications for methyl cyanide sources and sinks, J. Geophys. Res., 102, 25501-25506, 1997.

Seto, Y., Tsunoda, N., Ohta, H., and Shinohara, T.: Determination of blood cyanide by headspace gas chromatography with nitrogenphosphorous detection and using megabore capillary column, Anal. Chim. Acta., 276, 247-259, 1993.

Shim, C., Wang, Y., Singh, H. B., Blake, D. R., and Guenther, A. B.: Source characteristics of oxygenated volatile organic compounds and hydrogen cyanide, J. Geophys. Res., 112, D10305, doi:10.1029/2006JD007543, 2007.

Shimadzu Corporation: Flame thermionic detector for capillary columns, FTD-2014c user's manual, Shimadzu Corporation, Kyoto, Japan, 2004.

Singh, H. B., Salas, L., Herlth, D., Kolyer, R., Czech, E., Viezee, W., Li, Q., Jacob, D. J., Blake, D., Sachse, G., Harward, C. N., Fuelberg, H., Kiley, C. M., Zhao, Y., and Kondo, Y.: In situ measurements of $\mathrm{HCN}$ and $\mathrm{CH}_{3} \mathrm{CN}$ over the Pacific Ocean: sources, sinks, and budgets, J. Geophys. Res., 108, 8795, doi:10.1029/2002JD003006, 2003.
Sive, B. C., Zhou, Y., Troop, D., Wang, Y., Little, W. C., Wingenter, O. W., Russo, R. S., Varner, R. K., and Talbot, R.: Development of a cryogen-free concentration system for measurements of volatile organic compounds, Anal. Chem., 77, 6989-6998, 2005.

Španìl, P., Wang, T., and Smith, D.: Quantification of hydrogen cyanide in humid air by selected ion flow tube mass spectrometry, Rapid Commun. Mass Spectrom., 18, 1869-1873, 2004.

Talbot, R., Mao, H., and Sive, B. C.: Diurnal characteristics of surface level $\mathrm{O}_{3}$ and other important trace gases in New England, J. Geophys. Res., 110, D09307, doi:10.1029/2004JD005449, 2005.

Talbot, R., Mao, H., Feddersen, D., Smith, M., Kim., S. Y., Sive, B., Haase, K., Ambrose, J., Zhou, Y., and Russo, R.: Comparison of particulate mercury measured with manual and automated methods, Atmosphere, 2, 1-20, doi:10.3390/atmos2010001, 2011.

van de Weijer, P., Zwerver, B. H., and Lynch, R. J.: Spectroscopic investigation of the mechanisms of the alkali bead detector for gas chromatography, Anal. Chem., 60, 1380-1387, 1988.

Vetter, J.: Plant cyanogenic glycosides, Toxicon, 38, 11-36, 2000.

VICI Metronics, Inc.: Generating calibration gas standards with Dynacal ${ }^{\circledR}$ permeation devices, Technical Note 1001, Poulsbo, Washington, USA, 2004.

White, M. L., Russo, R. S., Zhou, Y., Mao, H., Varner, R. K., Ambrose, J., Veres, P., Wingenter, O. W., Haase, K., Stutz, J., Talbot, R., and Sive, B. C.: Volatile organic compounds in northern New England marine and continental environments during the ICARTT 2004 campaign, J. Geophys. Res., 113, D08S90, doi:10.1029/2007JD009161, 2008.

Yamamoto, N., Nishiura, H., Honjo, T., and Inoue, H.: Determination of ammonia in the atmosphere by gas chromatography with a flame thermionic detector, Anal. Sci., 7, 1041-1044, 1991.

Yamamoto, N., Nishiura, H., Honjo, T., Ishikawa, Y., and Suzuki, K.: Continuous determination of atmospheric ammonia by an automated gas chromatographic system, Anal. Chem., 66, 756760, 1994.

Yokelson, R. J., Urbanski, S. P., Atlas, E. L., Toohey, D. W., Alvarado, E. C., Crounse, J. D., Wennberg, P. O., Fisher, M. E., Wold, C. E., Campos, T. L., Adachi, K., Buseck, P. R., and Hao, W. M.: Emissions from forest fires near Mexico City, Atmos. Chem. Phys., 7, 5569-5584, doi:10.5194/acp-7-5569-2007, 2007.

Zhao, Y., Strong, K., Kondo, Y., Koike, M., Matsumi, Y., Irie, H., Rinsland, C. P., Jones, N. B., Suzuki, K., Nakajima, H., Nakane, H., and Murata, I.: Spectroscopic measurements of tropospheric $\mathrm{CO}, \mathrm{C}_{2} \mathrm{H}_{6}, \mathrm{C}_{2} \mathrm{H}_{2}$, and $\mathrm{HCN}$ in northern Japan, J. Geophys. Res., 107, 4343, doi:10.1029/2001JD000748, 2002. 